Studia Źródłoznawcze, t. LV

p-ISSN 0081-7147

e-ISSN 2451-1331

\title{
Kontakty personalne i instytucjonalne Jana Długosza z krakowskim środowiskiem uniwersyteckim. Uwagi o stanie i perspektywach badań
}

\begin{abstract}
Zarys treści: Autor omawia powiązania wybitnego historiografa polskiego Jana Długosza (1415-1480) z Uniwersytetem Krakowskim. Najpierw charakteryzuje dotychczasowe badania polskich historyków dotyczące studiów uniwersyteckich J. Długosza oraz jego fundacji na rzecz Uniwersytetu, a także bezpośrednich kontaktów i współpracy historiografa z krakowskimi profesorami w rozmaitych sprawach Kościoła krakowskiego i Królestwa Polskiego. Następnie wskazuje na nowe możliwości badań nad relacjami J. Długosza z krakowskimi uczonymi, szczególnie w kręgu kapituły katedralnej i kurii biskupiej.

Abstract: The author discusses the relationship between the outstanding Polish historiographer Jan Długosz (1415-1480 ) and Cracow University. First, he outlines the previous research that has been done by Polish historians on the university studies of Jan Dhugosz and his foundation for the university, together with his direct contacts and cooperation with Cracovian professors in various matters related to the Cracow Church and the Polish Kingdom. Next, the author indicates new possibilities for research into the relationships between Jan Długosz and Cracovian scholars, especially in the circle of cathedral chapter and the bishop's curia.
\end{abstract}

Słowa kluczowe: Jan Długosz, Uniwersytet Krakowski, fundacja, kapituła katedralna, konsystorz, dyplomacja

Keywords: Jan Długosz, Cracow University, foundation, cathedral chapter, consistory, diplomacy

Jan Długosz tylko przez trzy lata (1428-1431) był studentem Uniwersytetu Krakowskiego na Wydziale Sztuk Wyzwolonych. Z nieznanych dla nas przyczyn nie zdobył stopnia bakałarza artium, ale zyskał w nim pewną formację intelektualną. Następnie porzucił dalsze studia i związał się z kancelarią biskupa Zbigniewa Oleśnickiego ${ }^{1}$. Nie został więc człowiekiem Uniwersytetu, choć w jego imieniu, za urzędowania rektora Macieja z Łabiszyna, doktora teologii, złożył obediencję papieżowi Mikołajowi V w 1449 r. ${ }^{2}$ Przynależał do najbliższych współpracowników Oleśnickiego i stał

\footnotetext{
${ }^{1}$ Vita Ioannis Dlugosch senioris canonici Cracoviensis, red. M. Brożek, Cracoviae 1961, s. 30-31; M. Bobrzyński, S. Smolka, Jan Dlugosz, jego życie i stanowisko w piśmiennictwie, Kraków 1893, s. 6-18; M. Koczerska, Dlugosz jako sekretarz Zbigniewa Oleśnickiego, w: Jan Dlugosz w pięćsetna rocznicę śmierci. Materiały z sesji (Sandomierz 24-25 maja 1980 r.), red. F. Kiryk, Olsztyn 1983, s. 53-63.

${ }^{2}$ K. Ożóg, 'Ne contrarii haberemur doctrinae et scripturis nostris'. Droga Uniwersytetu Krakowskiego do złożenia obediencji papieżowi Mikołajowi V, w: Narodziny Rzeczypospolitej. Studia z dziejów średniowiecza i czasów wczesnonowożytnych, t. 2, red. W. Bukowski, T. Jurek, Kraków 2012, s. 1203-1204.
} 
się członkiem kapituły katedralnej, w której jako kanonik zasiadał przez 44 lata ${ }^{3}$. Przez całe życie spotykał się i współpracował z mistrzami krakowskiej wszechnicy na rozmaitych polach swojej działalności kościelnej, państwowej, fundacyjnej i pisarskiej. Z ogromną atencją odnosił się do Uniwersytetu Krakowskiego i był jego wielkim dobrodziejem, fundatorem Bursy Kanonistów. Jako egzekutor testamentu Zbigniewa Oleśnickiego czuwał nad dokończeniem budowy i urządzeniem Bursy Jerozolimskiej, a po pożarze w 1462 r. zatroszczył się o szybką jej odbudowę. Doprowadził też do powiększenia i nadania nowego kształtu architektonicznego Bursie Ubogich, a także przyczynił się do powstania Bursy Węgierskiej . Swoje opus vitae - Roczniki - powierzył przed śmiercią mistrzom Uniwersytetu, aby je kontynuowali. Usilnie wręcz ich błagał, ,żeby wydzielili jedną kolegiaturę, i to spośród lepszych, i dodali jej specjalnego magistra biegłego w studiach i humaniorach; ten zwolniony z wszelkich prac, robót i zajęć, niech się zajmuje tylko rocznikami"s. Również Banderia Prutenorum z woli Długosza trafiły do biblioteki Uniwersytetu Krakowskiego ${ }^{6}$. Relacje Długosza ze środowiskiem uniwersyteckim miały bez wątpienia charakter wyjątkowy, ale nie doczekały się wszechstronnego opracowania.

W dotychczasowej historiografii omawiano już fundacje Długosza na rzecz Uniwersytetu Krakowskiego i wskazywano na jego bliskie relacje z niektórymi mistrzami tej wszechnicy. Należy tu wspomnieć przede wszystkim klasyczne dzieła Michała Bobrzyńskiego i Stanisława Smolki o Janie Długoszu ${ }^{7}$ oraz Kazimierza Morawskiego o Uniwersytecie Krakowskim w wiekach średnich i okresie odrodzenia ${ }^{8}$. Z nowszej literatury na uwagę zasługują prace podejmujące niektóre wątki dotyczące kontaktów dziejopisarza z uczonymi krakowskimi: ks. Bolesława Przybyszewskiego o kapitule katedralnej w czasach Długosza ${ }^{9}$, Jadwigi Krzyżaniakowej o otoczeniu intelektualnym Jana Długosza ${ }^{10}$, Marii Koczerskiej o mentalności Długosza i jego służbie dla Zbigniewa Oleśnickiego ${ }^{11}$, Krystyny Pieradzkiej o związkach Długosza z Krakowem ${ }^{12}$, Marii Kowalczyk o lekturach Długosza ${ }^{13}$, Urszuli Borkowskiej o wpływie niektórych krakowskich uczonych na poglądy Długosza o Kościele, husytach i poganach ${ }^{14}$, Piotra Rabieja o uczonych w służbie biskupa Oleśnickiego ${ }^{15}$, Mariana Biskupa ${ }^{16}$, Jacka Wiesiołowskiego ${ }^{17}$, Sławomira Gawlasa ${ }^{18}$

\footnotetext{
3 Vita Ioannis Dlugosch, s. 36, 47-50; M. Bobrzyński, S. Smolka, Jan Dlugosz, s. 18-47, 84-87; B. Przybyszewski, Kapituła krakowska za kanonikatu Jana Dtugosza (1436-1480), w: Dlugossiana. Studia historyczne w pięćsetlecie śmierci Jana Dlugosza, red. S. Gawęda, Kraków 1980, s. 25-26.

4 Vita Ioannis Dlugosch, s. 38-39, 57-59; A. Włodarek, Architektura średniowiecznych kolegiów i burs Uniwersytetu Krakowskiego, Kraków 2000, s. 278-285, 344-347, 384-387, 411-415.

5 J. Długosz, Roczniki czyli Kroniki sławnego Królestwa Polskiego, ks. 12: 1462-1480, tłum. J. Mrukówna, kom. K. Baczkowski i in., Warszawa 2006, s. 462.

${ }^{6}$ K. Stopka, Na wieczysta pamiątke i symbol. Banderia Prutenorum: dzieło, autorzy, losy, w: J. Długosz, Banderia Prutenorum, red. Z. Pietrzyk, Kraków-Proszówki 2009, s. 30.

7 M. Bobrzyński, S. Smolka, Jan Dlugosz.

${ }^{8}$ K. Morawski, Historia Uniwersytetu Jagiellońskiego. Średnie wieki i odrodzenie, t. 1-2, Kraków 1900.

9 B. Przybyszewski, Kapituła krakowska, s. 25-82.

10 J. Krzyżaniakowa, Otoczenie intelektualne Jana Dlugosza, w: Jan Dlugosz w pięćsetna rocznicę śmierci, s. 31-43.

${ }^{11}$ M. Koczerska, Mentalność Jana Dlugosza w świetle jego twórczości, St. Źródł., 15, 1970, s. 109-140; taż, Dlugosz jako sekretarz, s. 53-63; taż, Zbigniew Oleśnicki i Kościół krakowski w czasach jego pontyfikatu 1423-1455, Warszawa 2004, s. $47-54$.

${ }^{12}$ K. Pieradzka, Jan Dlugosz a Uniwersytet Jagielloński, „Małopolskie Studia Historyczne”, 6, 1964, z. 3-4, s. 43-57; taż, Związi Dlugosza z Krakowem, Kraków 1975, s. 32-60.

${ }_{13}$ M. Kowalczyk, Marginalia Jana Dlugosza na rękopisie BJ 1210 „De civitate Dei” św. Augustyna, „Biuletyn Biblioteki Jagiellońskiej”, 18, 1966, z. 2, s. 59-66; taż, Jagiellońskie rękopisy Liwiusza z marginaliami Jana Długosza, „Eos”, 58, 1969/1970, z. 2, s. 219-230.

${ }^{14}$ U. Borkowska, Treści ideowe w dziełach Jana Dlugosza. Kościót i świat poza Kościołem, Lublin 1983.

15 P. Rabiej, Uczeni uniwersyteccy w stużbie i otoczeniu Zbigniewa Oleśnickiego, biskupa krakowskiego, w: Polska i jej sąsiedzi w późnym średniowieczu, red. K. Ożóg, S. Szczur, Kraków, s. 199-231.

${ }_{16}$ M. Biskup, Działalność dyplomatyczna Jana Dlugosza w sprawach pruskich w latach 1454-1466, w: Dlugossiana, s. 141-165.

17 J. Wiesiołowski, Sędziwój z Czechła (1410-1476). Studium z dziejów kultury umysłowej Wielkopolski, St. Źródł., 9, 1964, s. 99-100; tenże, Kolekcje historyczne w Polsce średniowiecznej XIV-XV wieku, Wrocław 1967, s. 98, $134,155$.

18 S. Gawlas, Świadomość narodowa Jana Dlugosza, St. Źródł., 27, 1983, s. 60-63.
} 
i Piotra Węcowskiego ${ }^{19}$ o grupie uczonych dyplomatów i ekspertów w służbie króla Kazimierza Jagiellończyka, Wojciecha Polaka o kontaktach Długosza z uczonymi krakowskimi w sprawach krzyżackich $^{20}$ czy Andrzeja Włodarka o średniowiecznych kolegiach i bursach Uniwersytetu Krakowskiego ${ }^{21}$. W niniejszym artykule postaram się naszkicować główne pola kontaktów Jana Długosza ze środowiskiem uniwersyteckim i możliwości badawcze w tym zakresie.

Stosunkowo duże zainteresowanie budził wśród badaczy trzyletni okres studiów Jana Długosza na Wydziale Sztuk w latach 1428-1431. Poczynając od wpisu do Metryki uniwersyteckiej w semestrze letnim 1428 r.: „Johannes Johannis Dlugossii de Nedzelsko solvit unum fertonem”22 [w nowoczesnym wydaniu: „Johannes Johannis $<\mid=$ Dlugossii=| de Nedzelsko $><$ st 1 fertonem $>$ "] ${ }^{23}$ ręką samego rektora Wawrzyńca z Raciborza. Pierwotnie w tym zapisie nie została odnotowana opłata immatrykulacyjna, którą najpewniej dopisał sam Długosz (,solvit unum fertonem”), co rozpoznała M. Kowalczyk ${ }^{24}$. Następnie starano się wskazać bardziej znaczące osoby, które wraz z Długoszem w 1428 r. immatrykulowały się na Uniwersytecie Krakowskim oraz mistrzów wykładających w latach 1428-1431 na fakultecie artium, a także postaci najwybitniejszych uczonych teologów, kanonistów i medyków (w tym rektorów), których mógł spotkać przyszły dziejopisarz w trakcie swych studiów ${ }^{25}$. W literaturze podniesiona została rola Jana Elgota, współrodowca Długosza, w ściągnięciu go na studia uniwersyteckie do Krakowa, a potem zaprotegowanie go Oleśnickiemu i wprowadzenie do kancelarii biskupiej ${ }^{26}$. Powiązania rodowe obu Wieniawitów (Długosz określił Elgota mianem ,patruus”) i ich wzajemne stosunki aż do śmierci Elgota w 1452 r. wymagają szczegółowych badań analitycznych

Po opuszczeniu wszechnicy kariera Długosza rozwijała się najpierw w otoczeniu biskupa Zbigniewa Oleśnickiego i kapituły katedralnej krakowskiej, a potem w służbie króla Kazimierza Jagiellończyka i Królestwa Polskiego. W tych wszystkich kręgach, a więc na dworze biskupa, w kapitule i dyplomacji królewskiej, Długosz spotykał się i w rozmaity sposób współdziałał z mistrzami Uniwersytetu Krakowskiego. J. Krzyżaniakowa starała się wymienić i ogólnie scharakteryzować osoby ze stopniami uniwersyteckimi, z którymi się zetknął w swym życiu i działalności ${ }^{27}$. Badania poznańskiej mediewistki ograniczyły się praktycznie do zarejestrowania wykształconych osób, przypisanych do konkretnych kręgów, a pozostających w pewnych lub domniemanych relacjach z dziejopisarzem. Nie miały one kompleksowego charakteru, przede wszystkim w odniesieniu do kapituły katedralnej, a także nie podejmowały ani kwestii czasu trwania, ani jakości kontaktów Długosza z krakowskimi uczonymi.

Dla pełnego obrazu koleżeńskich powiązań dziejopisarza z czasów studiów należałoby przynajmniej opracować prozopograficznie całą grupę 177 studentów wpisanych do Metryki w 1428 r., a także tych immatrykulowanych $\mathrm{w}$ dwóch następnych latach ${ }^{28}$ oraz grono bakałarzy i mistrzów artium z Wydziału Sztuk, na których wykłady, dysputy i repetytoria mógł uczęszczać Długosz w latach 1428-1431. Przykład takiego studium nad studentami z roku 1400/1401 dał Antoni Gąsiorowski ${ }^{29}$. Dopiero takie badania umożliwią ustalenie grupy osób, z którymi Długosz wszedł w bliższą znajomość i kontakty w czasie studiów, a także uchwycić późniejsze powiązania między tymi osobami. Do tej pory bardzo wybiórczo

\footnotetext{
19 P. Węcowski, Mazowsze w Koronie. Propaganda i legitymizacja władzy Kazimierza Jagiellończyka na Mazowszu, Kraków 2004, s. 259-288.

${ }^{20}$ W. Polak, Aprobata i spór. Zakon krzyżacki jako instytucja kościelna w dziełach Jana Dlugosza, Lublin 1999, s. 46-86.

${ }^{21}$ A. Włodarek, Architektura średniowiecznych kolegiów i burs, s. 278-285, 344-346, 384-386, 411-413.

22 BJ, rkps 258, s. 78.

${ }^{23}$ Metryka Uniwersytetu Krakowskiego z lat 1400-1508, t. 1-2, wyd. A. Gąsiorowski, T. Jurek, I. Skierska, współpr. R. Grzesik, Kraków 2004, tu t. 1, s. 140 [28e/029].

24 Tamże, przyp. 283.

${ }^{25}$ K. Pieradzka, Jan Dlugosz a Uniwersytet Jagielloński, s. 43-45; taż, Związki Dlugosza z Krakowem, s. 32-50; J. Krzyżaniakowa, Otoczenie intelektualne, s. 32-41.

${ }^{26}$ K. Pieradzka, Jan Dlugosz a Uniwersytet Jagielloński, s. 47-48; taż, Związi Dlugosza z Krakowem, s. 32-33, 36; J. Krzyżaniakowa, Otoczenie intelektualne, s. 36-37.

27 J. Krzyżaniakowa, Otoczenie intelektualne, s. 31-43.

${ }_{28}^{28}$ Metryka Uniwersytetu Krakowskiego, t. 1, s. 138-154.

29 A. Gąsiorowski, Pierwsi studenci odnowionego Uniwersytetu Krakowskiego (1400/1401), Rocz. Hist., 71, 2005, s. 63-98.
} 
skupiano się wyłącznie na kilku bardziej znanych postaciach, które razem z Długoszem rozpoczęły naukę na Wydziale Sztuk (Jakub z Szadka, Grzegorz z Sanoka, Grzegorz z Mysłowic, Jan Rzeszowski, Dziersław z Rytwian), a także niektórych osobach immatrykulowanych w 1429 r. (Piotr z Dzwonowa, Michał z Kleparza, Mikołaj z Krakowa i Stanisław z Kobylina) ${ }^{30}$. Spośród mistrzów wykładających w okresie studiów Długosza K. Pieradzka i J. Krzyżaniakowa wymieniały: Macieja z Łabiszyna, Jana Dąbrówkę, Zygmunta z Pyzdr, Pawła z Pyskowic, Sędziwoja z Czechla, Jana Orienta, Świętosława z Wojcieszyna, Tomasza Strzępińskiego, Jana z Radochoniec, Jana Puszkę z Krakowa i Stanisława Sobniowskiego ${ }^{31}$. Ta lista mistrzów na Wydziale Sztuk była tworzona głównie na podstawie Księgi promocji. Wspomniane badaczki wpisały na nią najbardziej znane osoby spośród promowanych magistrów z lat 1424-142932. Należy podkreślić, że krąg mistrzów, których wykładów i dysput słuchał przyszły dziejopisarz, możliwy jest jedynie do hipotetycznego odtworzenia. Punktem wyjścia są najstarsze statuty fakultetu artium z lat 1404-1406, określające obowiązkowe lektury dla uzyskania stopnia bakałarza i magistra ${ }^{33}$. Brak księgi pilności z tego okresu uniemożliwia nam precyzyjne ustalenie grona mistrzów, którzy prowadzili wykłady w latach 1428-1431. Natomiast pomocne są lista wysłuchanych wykładów i ćwiczeń, odbytych przed uzyskaniem bakalaureatu przez Jodoka z Głuchołazów z 1418 r. ${ }^{34}$ oraz scheda pro gradu magisterii Mikołaja z Ziębic (wpisany do Metryki w 1429 r., bakałarz w 1431 r., magister w 1437 r.), zawierająca spis wykładów, ćwiczeń oraz mistrzów, których słuchał wspomniany Mikołaj przed promocją na magistra artium ${ }^{35}$. Oba te wykazy potwierdzają, że program zapisany w statutach był realizowany, a grono mistrzów liczyło kilkanaście osób ${ }^{36}$. Dotychczas badacze byli skazani na szczątkowe informacje źródłowe i przypuszczenia w sprawie określenia grupy mistrzów, na których wykłady uczęszczał przyszły dziejopisarz. Tak było nawet w przypadku Jana Dąbrówki, brak bowiem bezpośredniego dowodu na to, że Długosz słuchał jego wykładu (komentarza) o Kronice Wincentego Kadłubka. W okresie studiów Długosza (1428-1431) Dąbrówka wykładał gramatykę i retorykę na katedrze z fundacji Nowki. Wówczas komentarz do Kroniki Wincentego nie tylko nie był gotowy, ale nawet mistrz nie rozpoczął jego pisania ${ }^{37}$. $Z$ tym Komentarzem w spisanej postaci Długosz zapoznał się już po opuszczeniu Uniwersytetu, w późniejszych latach. Dopiero szeroko zakrojone badania prozopograficzne nad bakałarzami, magistrami i doktorami wszystkich czterech fakultetów pozwolą na określenie grupy mistrzów prowadzących wykłady na Wydziale Sztuk. Ułatwi je Corpus academicum Cracoviense - elektroniczna baza wszystkich studentów i profesorów Uniwersytetu Krakowskiego z lat 1364-1780, która powstaje obecnie na Wydziale Historycznym UJ i Archiwum UJ w ramach projektu Narodowego Programu Rozwoju Humanistyki (nr 11H 120264 81).

Z urzędującymi w latach 1428-1431 rektorami Uniwersytetu i dziekanami Wydziału Sztuk Długosz stykał się w czasie uroczystości ogólnouniwersyteckich, np. mszy, zebrań z lekturą i eksplikacją statutów oraz promocji. Rektorami Uniwersytetu Krakowskiego we wspomnianym okresie, obok

${ }^{30}$ K. Pieradzka, Jan Dlugosz a Uniwersytet Jagielloński, s. 43-44; taż, Zwiazki Długosza z Krakowem, s. 39-42; J. Krzyżaniakowa, Otoczenie intelektualne, s. 32.

${ }^{31}$ K. Pieradzka, Jan Dlugosz a Uniwersytet Jagielloński, s. 44-45; taż, Zwiazki Dlugosza z Krakowem, s. 43-47; J. Krzyżaniakowa, Otoczenie intelektualne, s. 33.

32 Najstarsza księga promocji Wydziału Sztuk Uniwersytetu Krakowskiego z lat 1402-1541, wyd. A. Gąsiorowski, T. Jurek, I. Skierska, Warszawa 2011, s. 203-206.

33 Statuta nec non liber promotionum philosophorum ordinis in Universitate studiorum Jagellonica ab anno 1402 ad annum 1849, red. J. Muczkowski, Cracoviae 1849, s. XII-XIII; K. Ożóg, Zakres i metody nauczania „, septem artes” na Wydziale Sztuk Uniwersytetu Krakowskiego w XV wieku, w: Septem artes w kształtowaniu kultury umysłowej w Polsce średniowiecznej (wybrane zagadnienia), red. T. Michałowska, Wrocław 2007, s. 110-111.

${ }^{34}$ K. Morawski, Historia Uniwersytetu Jagiellońskiego, t. 1, s. 211-213; K. Ożóg, Zakres i metody, s. 111-112.

${ }_{35}$ BJ, rkps 243, k. 1r-v; Statuta nec non liber promotionum, s. CXLII-CXLV; K. Ożóg, Zakres i metody, s. 112-113.

${ }^{36}$ K. Ożóg, Zakres i metody, s. 110-113.

37 M. Zwiercan, Komentarz Jana z Dąbrówki do Kroniki mistrza Wincentego zwanego Kadtubkiem, Wrocław 1969, s. 85-113, 175-176; tenże, Zainteresowania historyczne społeczności Uniwersytetu Krakowskiego w XV wieku, w: Literatura i kultura późnego średniowiecza w Polsce, red. T. Michałowska, Warszawa 1993, s. 43-47; tenże, Historia badań nad Jana Dąbrówki Komentarzem do „Kroniki polskiej” mistrza Wincentego zwanego Kadlubkiem, w: Komentarz Jana z Dąbrówki do Kroniki biskupa Wincentego, red. A. Dąbrówka, M. Olszewski, Studia Staropolskie, Series Nova, t. 42(98), Warszawa 2015, s. 15-27. 
wymienionego wyżej Wawrzyńca z Raciborza, byli: Andrzej z Kokorzyna, Franciszek z Brzegu, Jan z Wielunia, Andrzej z Buku i Jan z Radochoniec ${ }^{38}$. Natomiast dziekanami Wydziału Sztuk byli: Mikołaj Tempelfeld z Brzegu, Jan z Jarząbi, Jan Czelp z Wielunia, Paweł z Pyskowic, Stanisław z Pierzchowa, Mikołaj z Głubczyc ${ }^{39}$. Z tego grona mistrzów w późniejszych latach Długosz spotkał w kapitule Jana z Radochoniec i Pawła z Pyskowic ${ }^{40}$. Natomiast najpierw przez swego krewnego Jana Elgota, a potem osobiście mógł utrzymywać kontakt z Mikołajem Tempelfeldem, zarówno w Krakowie, jak i po przeniesieniu się Tempelfelda do Wrocławia ${ }^{41}$.

Duże możliwości badań nad relacjami dziejopisarza z kręgiem profesorów krakowskiej wszechnicy stwarzają źródła kapitulne i konsystorskie, a także dokumenty biskupów krakowskich, kapituły oraz prałatów i kanoników wystawiane w rozmaitych sprawach przy okazji posiedzeń kapituły. Zachowana od 1438 r. Metryka kapituły katedralnej, choć mało starannie prowadzona, wraz z listami świadków wspomnianych wyżej dokumentów pozwala ustalić grupę mistrzów uniwersyteckich uczestniczących w posiedzeniach kapituły z racji posiadanych prałatur lub kanonii ${ }^{42}$. Długosz rezydował głównie w Krakowie, wyjeżdżając jedynie dla załatwienia spraw powierzanych mu przez biskupów, kapitułę i dwór królewski oraz własnych, np. pielgrzymując do Rzymu i Ziemi Świętej. Dlatego też przeważnie uczestniczył w posiedzeniach kapituły. To właśnie otwierało przed nim możliwości regularnych kontaktów i spotkań z uczonymi uniwersyteckimi ${ }^{43}$.

Na mocy donacji biskupa Piotra Wysza z 1401 r. dwie kanonie należały do Uniwersytetu. Były one powierzane profesorom prawa kanonicznego i teologii, stąd w czasach Długosza w kapitule było zawsze co najmniej dwóch mistrzów uniwersyteckich ${ }^{44}$. Ponadto wchodzili oni do kapituły również inną drogą poprzez prowizję biskupa czy papieża, obejmując kanonie i prałatury. W 1436 r., kiedy Długosz po śmierci Jana Rzeszowskiego, arcybiskupa lwowskiego, otrzymał kanonię katedralną, w kapitule zasiadali następujący profesorowie: archidiakon Dziersław z Borzymowa, doktor dekretów, kantor Mikołaj Spycimir z Krakowa, doktor dekretów, kanonicy: Adam z Będkowa, doktor dekretów, Jan Elgot, doktor dekretów, Jakub z Zaborowa, doktor dekretów i Tomasz Strzępiński, wówczas doktor dekretów oraz Jan z Radochoniec, doktor teologii, który po sporze z Mikołajem z Kozłowa wszedł w posiadanie kanonii w końcu $1435 \mathrm{r} .^{45}$

Niebawem po wejściu Długosza do kapituły grono mistrzów uniwersyteckich w tej korporacji się powiększyło. I tak w 1436 r. kanonikiem został doktor dekretów Jan Puszka z Krakowa, a w 1437 r. Jan Pniowski, późniejszy doktor dekretów (1448), kilkakrotny rektor Uniwersytetu, archidiakon od 1450 r., w 1438 r. zaś kanonię katedralną objął doktor dekretów Paweł z Zatora, a w 1441 r. Stanisław Sobniowski, były dziekan Wydziału Sztuk i przyszły rektor. Z kolei 4 XI 1443 wspomniany wyżej Mikołaj z Kozłowa otrzymał prowizję na kanonię katedralną od biskupa Zbigniewa Oleśnickiego, ale dwa dni później zmar ${ }^{46}$. Przez kilkanaście lat ta grupa kanonistów i teologów w kapitule nie ulegała większym zmianom. Kilku z nich zmarło w połowie XV w.: Jakub z Zaborowa (1449), Jan Puszka (1450), Jan z Radochoniec (1450), Adam z Będkowa (1451), Dziersław z Borzymowa (1452) i Jan Elgot (1452)

${ }^{38}$ Metryka Uniwersytetu Krakowskiego, t. 1, s. LIII-LIV, 138-139, 143, 145, 146, 148, 149, 154; Z. Pietrzyk, Poczet rektorów Uniwersytetu Jagiellońskiego 1400-2000, Kraków 2000, s. 30-31, 50, 55-57.

39 Najstarsza księga promocji, s. 205-207, 417.

40 B. Przybyszewski, Kapituła krakowska, s. 77.

${ }^{41}$ M. Kowalczykówna, Mikołaj Tempelfeld z Brzegu, w: PSB, t. 21, Wrocław 1976, s. 107-109.

${ }^{42}$ Archiwum i Biblioteka Kapituły Metropolitalnej w Krakowie, Acta actorum Capituli Ecclesiae Cathedralis Cracoviensis, t. $1 \mathrm{a}, 1 \mathrm{~b}, 2$.

${ }^{43}$ Tamże; M. Bobrzyński, S. Smolka, Jan Dlugosz, s. 222-311; A. Perzanowska, Wiadomości źródłowe o życiu i działalności Jana Dlugosza, w: Dlugossiana, s. 293-365; B. Przybyszewski, Kapituła krakowska, s. 25-82.

${ }^{44}$ Z. Kozłowska-Budkowa, Odnowienie jagiellońskie Uniwersytetu Krakowskiego (1390-1414), w: Dzieje Uniwersytetu Jagiellońskiego w latach 1364-1764, t. 1, red. K. Lepszy, Kraków 1964, s. 49.

45 B. Przybyszewski, Kapituła krakowska, s. 30-31, 40-41, 72-75.

46 Tamże, s. 74-77; K. Ożóg, Mistrza Mikołaja z Kozłowa poglady na władzę i państwo, w: Ecclesia, cultura, potestas. Studia z dziejów kultury i społeczeństwa. Księga ofiarowana siostrze profesor Urszuli Borkowskiej, red. P. Kras i in., Kraków 2006, s. $420-421$.

47 B. Przybyszewski, Kapituła krakowska, s. 56-57, 73-77. 
To spowodowało zmiany w składzie kapituły, ale grupa mistrzów z Uniwersytetu nie uległa zbytniemu pomniejszeniu, kanonie otrzymali bowiem doktorzy dekretów Michał z Szydłowa (1447), Jakub Parkoszowic z Żurawicy (1449) i Mikołaj z Kalisza (1454), doktorzy teologii Benedykt Hesse (1450) i Paweł z Pyskowic (1456), a licencjat dekretów Kacper Rokenberg objął na mocy prowizji kardynała Oleśnickiego scholasterię po Janie Elgocie w 1453 r. ${ }^{48}$

Kolejni uczeni uniwersyteccy zasiedli w kapitule w następnych latach, byli to doktorzy dekretów: Maciej z Błędowa (1462), Jakub z Szadka (1464), Stanisław z Kobylina (1465), Jan Baruchowski (1469), Jan Latoszyński (1472), Arnolf z Mierzyńca (1474), Sędziwój Tęczyński (1457, licencjatem dekretów został w 1462 r.), doktorzy teologii: Jan z Dąbrówki (również doktor dekretów) (1467), Jan ze Słupczy (1472), Mikołaj Bylina z Leszczyn (1472), Jakub z Lisowa (doktor dekretów) (1474), doktor medycyny Jan Stanko (1469) ${ }^{49}$.

Niektórzy z wymienionych kanonistów pełnili urzędy oficjała (Jan Elgot, Jan z Pniowa, Sędziwój z Tęczyna, Jan z Latoszyna) i wikariusza generalnego in spiritualibus (Jan Elgot, Paweł z Zatora, Mikołaj z Kalisza, Stanisław z Kobylina, Maciej z Błędowa, Mikołaj Bylina, Jan ze Słupczy, Jakub z Szadka), co stwarzało Długoszowi dodatkową płaszczyznę kontaktu z tymi uczonymi, akta oficjalatu poświadczają bowiem wiele spraw, które załatwiał on w konsystorzu krakowskim ${ }^{50}$. Wśród surogatów Jana Elgota, oficjała i wikariusza generalnego, był kanonista z Uniwersytetu Krakowskiego, doktor dekretów Stanisław z Uścia Solnego (1434-1437) ${ }^{51}$.

Z tej grupy uczonych nieco lepiej rozpoznane są relacje Długosza z Jakubem z Szadka, Janem Dąbrówką, Mikołajem z Kalisza, głównie na gruncie działalności eksperckiej w dyplomacji królewskiej i zainteresowań historiograficznych. Do tego grona należy dołączyć Sędziwoja z Czechla, chociaż nie był on członkiem kapituły katedralnej krakowskiej. Z Sędziwojem łączyła Długosza przyjaźń intelektualna od czasów wspólnej pracy w charakterze ekspertów w sprawach krzyżackich i mazowieckich ${ }^{52}$. Najdłużej - zapewne już od czasu studiów - trwały kontakty Jana Długosza z Jakubem z Szadka ${ }^{53}$. W 1455 r. na sejmie król nobilitował Jakuba, Długosz zaś przypuścił go do swojego herbu Wieniawa. Dwa lata później obaj byli zaangażowani w spłatę należności zaciężnym krzyżackim w Prusach przy wykupie zamku malborskiego. Od tego czasu współdziałali w charakterze ekspertów i dyplomatów królewskich w sprawach krzyżackich, mazowieckich, czeskich i węgierskich. Po wejściu Jakuba z Szadka do kapituły w 1464 r. ich współpraca uległa jeszcze poszerzeniu. W 1471 r. po śmierci Jana Długosza młodszego Jakub nawet zamieszkał w kanonickim domu Długosza, aż do 1480 r. Nie zerwał on łączności z Uniwersytetem, w latach 1475-1476 dwukrotnie pełnił bowiem urząd rektora ${ }^{54}$. Według M. Koczerskiej to zapewne Jakub z Szadka był autorem Żywota Długosza, pierwszej bogatej w szczegóły biografii dziejopisarza ${ }^{55}$.

Nieco inny charakter miała przyjaźń Jana Długosza z Janem Stanką, doktorem medycyny, mistrzem uniwersyteckim, który uratował życie dziejopisarzowi w 1471 r., gdy ten ciężko zachorował. Stanko

48 Tamże, s. 35, 56, 76-79.

49 Tamże, s. 57-58, 78-80.

${ }_{50}$ M. Kowalczykówna, Wypisy do biografii Jana Dlugosza z ksiag sądowych Kurii Metropolitalnej w Krakowie, „Analecta Cracoviensia", 12, 1980, s. 273-315; E. Knapek, Akta oficjalatu i wikariatu generalnego krakowskiego do połowy XVI wieku, Kraków 2010, s. 197-199, 206-209.

${ }^{51}$ E. Knapek, Akta oficjalatu, s. 214: M. Zwiercan, Stanisław z Uścia, w: PSB, t. 42, Warszawa-Kraków 2003, s. 94-95; K. Ożóg, Stanistaw z Uścia Solnego, w: K. Ożóg, K. Fokt, M. Mikuła, M. Zdanek, D. Wójcik-Zega, K. Kuras, Profesorowie Wydziału Prawa Uniwersytetu Jagiellońskiego, t. 1: 1364-1780, red. W. Uruszczak, Kraków 2015, s. 391-392.

52 P. Węcowski, Mazowsze w Koronie, s. 263-287; W. Drelicharz, Sędziwój z Czechla, w: PSB, t. 36, Warszawa-Kraków, s. 394-399; J. Wiesiołowski, Sędziwój z Czechła, s. 99-100.

${ }^{53}$ K. Pieradzka, Związi Dlugosza z Krakowem, s. 40-42.

${ }^{54}$ F. Kiryk, Jakub z Szadka, w: PSB, t. 10, Wrocław, s. 367-368; M. Koczerska, Kto jest autorem Żywotu Dlugosza?, w: Venerabiles, nobiles et honesti. Studia z dziejów społeczeństwa Polski średniowiecznej. Prace ofiarowane Profesorowi Januszowi Bieniakowi w siedemdziesiąta rocznicę urodzin i czterdziestopięciolecie pracy naukowej, red. A. Radzimiński, A. Supruniuk, J. Wroniszewski, Toruń 1997, s. 518-519; P. Węcowski, Mazowsze w Koronie, s. 270-271; M. Zdanek, Jakub z Szadka, w: Profesorowie Wydziatu Prawa Uniwersytetu Jagiellońskiego, t. 1, s. 105-107.

${ }_{55}$ M. Koczerska, Kto jest autorem, s. 507-520. 
przeprowadził niezwykłą operację, usuwając z pęcherza Długosza kamień (litotomia), który powodował codzienne wysokie gorączki ${ }^{56}$.

Możemy stwierdzić, że w kapitule katedralnej Długosz miał krócej bądź dłużej trwające kontakty z 30 uczonymi z Uniwersytetu Krakowskiego, w tym wybitnymi profesorami prawa kanonicznego, teologii i medycyny. Dopiero zbadanie tej grupy i uchwycenie wszelkich możliwych powiązań, spraw i kontaktów pozwoli na pełniejszą odpowiedź o relacje dziejopisarza ze środowiskiem uniwersyteckim.

Fundacje Długosza na rzecz Uniwersytetu sprzyjały intensyfikacji kontaktów z kolejnymi rektorami i ich konsyliarzami (niekiedy ze zgromadzeniem wszystkich mistrzów). Zabiegi Długosza o sfinalizowanie fundacji Bursy Jerozolimskiej w 1455 i 1456 r., podjętej przez kardynała Zbigniewa Oleśnickiego, przypadły na kadencje następujących rektorów: Mikołaja Byliny, Benedykta Hessego i Jana z Pniowa. Jej odbudowa po pożarze w 1462 r. nastąpiła zaś za rządów rektora Arnolfa z Mierzeńca ${ }^{57}$.

Zamysł rozbudowy Bursy Ubogich został podjęty przez Długosza w 1458 r. i był on realizowany w następnych latach, najpewniej do 1462 r. W kwietniu 1461 r. rektor Sędziwój Tęczyński lub Mikołaj Bylina z Leszczyn z całym Uniwersytetem przyłączył zakupiony przez Długosza dom mieszczański do wspomnianej bursy, która po przebudowie uzyskała nowy kształt architektoniczny i została znacznie powiększona ${ }^{58}$. Starania Długosza wokół fundacji Bursy Jerozolimskiej i rozbudowy Bursy Ubogich dowodzą kilkuletnich kontaktów z kolejnymi rektorami Uniwersytetu i jego mistrzami.

W styczniu 1464 r. Długosz był pełnomocnikiem Jana i Spytka z Melsztyna przy sprzedaży przez nich Uniwersytetowi kamiennego domu przy ul. św. Franciszka. Warunki tej transakcji zostały ustalone przez Długosza i rektora Arnolfa z Mierzeńca ${ }^{59}$. Najpierw w tym domu, zwanym Collegium Novum, odbywały się wykłady uniwersyteckie, a potem zorganizowano w nim bursę dla studentów węgierskich ${ }^{60}$.

Z kolei samodzielna fundacja Długosza Bursy Kanonistów została zrealizowana w ostatnim okresie jego życia. Za początek procesu fundacyjnego można uznać rok 1469, kiedy z jego inicjatywy doszło do likwidacji Bursy Grochowej (przy ul. Kanoniczej 5) i zamiany placów między kapitułą katedralną a Uniwersytetem. Rektor Jana Latoszyński wraz doktorami i magistrami zrzekł się terenu po wspomnianej Bursie, otrzymując w zamian od kapituły działkę na tyłach Kolegium Większego ${ }^{61}$. W następnych latach w związku z rozpoczętą fundacją bursy przy ul. Grodzkiej naprzeciw Collegium Iuridicum Długosz musiał utrzymywać bliższe stosunki z korporacją uniwersytecką, szczególnie kolejnymi rektorami, m.in. Jakubem z Szadka w 1475 r. i Janem Beberem z Oświęcimia w 1480 r. Za urzędowania tego ostatniego Długosz oficjalnie i formalnie przekazał Uniwersytetowi wybudowaną z cegły bursę nazwaną Collegium Longini. Wszechnicę obok rektora reprezentowali doktor teologii Stanisław z Brzezin i doktor dekretów Maciej z Kobylina ${ }^{62}$.

W 1449 r. Długosz nawiązał kontakty z Marcinem Królem z Żurawicy, który wówczas przebywał w Budzie jako nadworny medyk Jana Hunyadego, w związku z próbami pozyskania przez Zbigniewa Oleśnickiego tego uczonego dla Uniwersytetu i dla siebie jako lekarza. Ponadto dziejopisarz zabiegał wtedy poprzez Marcina Króla o wypożyczenie kopii dzieła Liwiusza, znajdującego się wówczas w posiadaniu znanego węgierskiego humanisty Jana Viteza ${ }^{63}$.

Długosz wytrwale zbierał dzieła potrzebne mu do pracy historiograficznej, dlatego kompleksowe badania nad jego biblioteką przyczynią się również do uchwycenia jego intelektualnych kontaktów z rozmaitymi osobami w Krakowie, Polsce i poza jej granicami. Wielu ważnych ustaleń dokonała na

56 Vita Ioannis Dlugosch, s. 52-53; P. Gąsiorowska, Stanko (Stanconis) Jan, w: PSB, t. 42, Warszawa-Kraków 2003-2004, s. 222-226.

${ }^{57}$ A. Włodarek, Architektura średniowiecznych kolegiów i burs, s. 345-346; Z. Pietrzyk, Poczet rektorów, s. 86.

${ }_{58} \mathrm{KDm} . \mathrm{K}$, cz. 2-4, nr 454, s. 595-596; A. Włodarek, Architektura średniowiecznych kolegiów i burs, s. 385-387.

${ }^{59}$ CDUJ, cz. 2, nr 208.

${ }^{60}$ A. Włodarek, Architektura średniowiecznych kolegiów i burs, s. 411-413.

${ }^{61}$ CDUJ, cz. 2, nr 224.

${ }^{62}$ CDUJ, cz. 3, nr 259.

${ }^{63}$ M. Kowalczyk, Jagiellońskie rękopisy Liwiusza, s. 221-222. 
tym polu M. Kowalczyk i kilku innych badaczy ${ }^{64}$. Interesujący przykład stanowią losy rękopisu 1210 Biblioteki Jagiellońskiej z De civitate Dei św. Augustyna. W 1435 r. skopiował ten rękopis w Bazylei Konrad syn Zygfryda, a w następnym roku zakupił go tam Tomasz Strzępiński i przywiózł do Krakowa. Kopia De civitate Dei była niezbyt staranna i zawierała wiele błędów i opuszczeń. Strzępiński zdecydował się na korektę rękopisu. Jak ustaliła M. Kowalczyk po wnikliwej analizie, kodeks najpierw trafił do Jana Elgota, który naniósł poprawki do s. 91, a potem staranną korektę całego tekstu dzieła św. Augustyna przeprowadził Długosz. Ponadto objaśniał on na marginesach niektóre wyrażenia, posługując się przy tym komentarzem Tomasza Waleys i Mikołaja Trevet. Można przypuszczać, że komentarz ten funkcjonował w środowisku krakowskim i na potrzeby korekty Długosz pożyczył go lub dostał od Tomasza Strzępińskiego, albo od kogoś innego ${ }^{65}$. Jeden z późniejszych rękopisów dzieła św. Augustyna z komentarzem posiadał Jakub z Szadka, który w 1477 r. ofiarował go Kolegium Większemu ${ }^{66}$.

Kontakty osobiste Jana Długosza z mistrzami uniwersyteckimi zachodziły w otoczeniu biskupa Zbigniewa Oleśnickiego, w kapitule katedralnej, urzędach kurii krakowskiej, na polu dyplomacji królewskiej. Współdziałał on z profesorami jako sędzia polubowny, egzekutor testamentów, poręczyciel, opiekun prawny itd. Dla przykładu w 1467 r. był obok profesorów Uniwersytetu Jana z Dąbrówki i Klemensa z Górki, doktora dekretów, sędzią polubownym w sporze Wojciecha z Żychlina, podkanclerzego koronnego, i Jana Piekarskiego, plebana w Pleszowie, o dziesięciny z folwarku w Pleszowie ${ }^{67}$. Wraz z Pawłem z Zatora i Maciejem z Milejowa był egzekutorem testamentu swego współrodowca Jana Elgota, zmarłego w 1452 r. ${ }^{68}$ W latach 1455-1456 razem z Maciejem z Sąspowa, mistrzem filozofii i bakałarzem teologii, występowali jako „factores Katharine Stymbarska et eiusdem testamenti et ultime voluntatis fideicommissarii" ${ }^{69}$. Od krakowskich mistrzów Długosz kupował lub pożyczał i kopiował rozmaite dzieła potrzebne mu w pracy pisarskiej. W ten sposób tworzył warsztat dziejopisarski. Uczeni należeli też do informatorów historiografa w wielu sprawach. Niektórych z nich szczerze podziwiał, jak np. Jana Elgota, Tomasza Strzępińskiego, Pawła z Zatora czy Sędziwoja z Czechla ${ }^{70}$.

Rozległa sieć powiązań i kontaktów Jana Długosza z kilkudziesięcioma uczonymi krakowskimi zasługuje na wszechstronne i systematyczne studia analityczne. Pozwolą one zdecydowanie pogłębić naukowe rozpoznanie intelektualnego wizerunku dziejopisarza i jego twórczości, a także relacji z najważniejszym środowiskiem umysłowym w Królestwie Polskim.

\section{Personal and institutional contacts of Jan Długosz with the community of Krakow University. Remarks on the research state and prospects}

Summary: Only for three years did Jan Długosz study liberal arts at the university of Cracow (1428-1431), but throughout his whole adult life he maintained contacts with the university community, especially with professors. The article presents, first, the state of research done by Polish historians on Jan Dlugosz university studies and his foundation for the university, then the personal contacts and cooperation of the chronicler with Cracovian professors in various matters of the Cracow Church and the Polish Kingdom. Texts by M. Bobrzyński and S. Smolka, K. Morawski, K. Pieradzka, B. Przybyszewski, J. Krzyżaniak, M. Koczerska, M. Kowalczyk, M. Biskup, S. Gaw-

${ }^{64}$ Taż, Marginalia Jana Dlugosza, s. 59-66; taż, Jagiellońskie rękopisy Liwiusza, s. 221-230; I. Zarębski, Humanistyczna lektura Dtugosza: Antonio Panormita Beccadelli, „Biuletyn Biblioteki Jagiellońskiej”, 17, 1965, z. 1, s. 5-21; M. Zwiercan, Rękopis Biblioteki Kapitulnej we Wroctawiu 5 n. Opis katalogowy, „Biuletyn Biblioteki Jagiellońskiej”, 17, 1965, z. 1, s. 23-28; J. Zathey, Biblioteka Jagiellońska w latach 1364-1492, w: Historia Biblioteki Jagiellońskiej, t. 1, cz. 1, red. I. Zarębski, Kraków, 1966, s. 125.

${ }_{65}$ M. Kowalczyk, Marginalia Jana Dlugosza, s. 59-66.

${ }^{66}$ Tamże, s. 59-60.

${ }^{67}$ KDMłp., t. 5, nr 759, za: <http://www.kodeks.pau.krakow.pl/dokumenty.html> [dostęp: 21.01.2017].

${ }^{68}$ Cracovia artificum. Supplementa. Teksty źródłowe do dziejów kultury i sztuki z archiwaliów kurialnych i kapitulnych w Krakowie. 1441-1450, wybór i oprac. B. Przybyszewski, Kraków 1993, nr 21, przyp. 1.

${ }^{69}$ M. Kowalczykówna, Wypisy do biografii, nr 20, 26, 31, 33.

${ }^{70}$ J. Krzyżaniakowa, Eruditio et scientia w Dlugoszowych wizerunkach władców i biskupów, w: Mente et litteris. O kulturze i społeczeństwie wieków średnich, red. H. Chłopocka i in., Poznań 1984, s. 272-273, 277-278. 
las, A. Włodarek and P. Węcowski deserve special attention in this regard. Next, the author of the article suggests new lines of research into Długosz's relationships with Cracovian scholars. The source material of the Cracow chapter and the consistory court together with documents issued by Cracow bishops, chapter, prelates and canons in various matters during the chapter sessions suggest high potential in this area. In 1436-1480, when Dhugosz was a member of the cathedral chapter, a large group of university professors were associated (around thirty persons), with whom the chronicler maintained personal contacts. A full and comprehensive knowledge of this group with all their possible interactions, matters and contacts will make it possible for us to better understand Jan Długosz's relations with the university milieu. The complex study of the chronicler's library will contribute to the knowledge of Długosz's intellectual contacts with various people in Cracow, Poland, and abroad.

Nota o Autorze: Krzysztof Ożóg, profesor zwyczajny Uniwersytetu Jagiellońskiego, kierownik Zakładu Historii Polski Średniowiecznej w Instytucie Historii UJ i dyrektor Archiwum Uniwersytetu Jagiellońskiego. Zajmuje się historią średniowiecza, szczególnie dziejami późnośredniowiecznej kultury umysłowej Polski i Europy.

Author: Krzysztof Ożóg, associate professor at the Jagiellonian University, head of the Department of Medieval History of Poland at the Faculty of History of Jagiellonian University, and director of the Jagiellonian University Archives. His research interests are in history of the Middle Ages, especially in the intellectual history of Poland and Europe in the late medieval period.

Instytut Historii

Uniwersytet Jagielloński

ul. Gołębia 13

31-007 Kraków

e-mail: krzysztof.ozog@uj.edu.pl

\section{Bibliografia}

\section{Źródta}

Codex diplomaticus Universitatis Studii Generalis Cracoviensis, cz. 2-3, [red. I.Ż. Pauli], Cracoviae 1873-1880 Długosz Jan, Roczniki czyli Kroniki sławnego Królestwa Polskiego, ks. 12: 1462-1480, tłum. J. Mrukówna, kom. K. Baczkowski i in., Warszawa 2006

Kodeks dyplomatyczny miasta Krakowa 1257-1506, cz. 2-4, wyd. F. Piekosiński, Kraków1882

Kowalczykówna M., Wypisy do biografii Jana Dlugosza z ksiag sądowych Kurii Metropolitalnej w Krakowie, „Analecta Cracoviensia”, 12, 1980, s. 273-315

Metryka Uniwersytetu Krakowskiego z lat 1400-1508, t. 1-2, wyd. A. Gąsiorowski, T. Jurek, I. Skierska, współpr. R. Grzesik, Kraków 2004

Najstarsza księga promocji Wydziatu Sztuk Uniwersytetu Krakowskiego z lat 1402-1541, wyd. A. Gąsiorowski, T. Jurek, I. Skierska, Warszawa 2011

Statuta nec non liber promotionum philosophorum ordinis in Universitate studiorum Jagellonica ab anno 1402 ad annum 1849, red. J. Muczkowski, Cracoviae 1849

Vita Ioannis Dlugosch senioris canonici Cracoviensis, red. M. Brożek, Cracoviae 1961

\section{Opracowania}

Biskup M., Działalność dyplomatyczna Jana Dlugosza w sprawach pruskich w latach 1454-1466, w: Dlugossiana. Studia historyczne w pięćsetlecie śmierci Jana Dlugosza, red. S. Gawęda, Kraków 1980, s. 141-165

Bobrzyński M., Smolka S., Jan Dlugosz, jego życie i stanowisko w piśmiennictwie, Kraków 1893

Borkowska U., Treści ideowe w dziełach Jana Dlugosza. Kościół i świat poza Kościołem, Lublin 1983

Gawlas S., Świadomość narodowa Jana Dlugosza, St. Źródł., 27, 1983, s. 3-66

Gąsiorowski A., Pierwsi studenci odnowionego Uniwersytetu Krakowskiego (1400/1401), Rocz. Hist., 71, 2005, s. 63-98

Knapek E., Akta oficjalatu i wikariatu generalnego krakowskiego do połowy XVI wieku, Kraków 2010

Koczerska M., Dlugosz jako sekretarz Zbigniewa Oleśnickiego, w: Jan Dlugosz w pięćsetna rocznice śmierci. Materiaty z sesji (Sandomierz 24-25 maja 1980 r.), red. F. Kiryk, Olsztyn 1983, s. 53-63

Koczerska M., Kto jest autorem Żywotu Dtugosza?, w: Venerabiles, nobiles et honesti. Studia z dziejów społeczeństwa Polski średniowiecznej. Prace ofiarowane Profesorowi Januszowi Bieniakowi w siedemdziesiata 
rocznice urodzin i czterdziestopięciolecie pracy naukowej, red. A. Radzimiński, A. Supruniuk, J. Wroniszewski, Toruń 1997, s. 507-520

Koczerska M., Mentalność Jana Długosza w świetle jego twórczości, St. Źródł., 15, 1970, s. 109-140

Koczerska M., Zbigniew Oleśnicki i Kościół krakowski w czasach jego pontyfikatu 1423-1455, Warszawa 2004

Kowalczyk M., Jagiellońskie rękopisy Liwiusza z marginaliami Jana Długosza, „Eos”, 58, 1969/1970, z. 2, s. 219-230

Kowalczyk M., Marginalia Jana Długosza na rękopisie BJ 1210 „De civitate Dei” św. Augustyna, „Biuletyn Biblioteki Jagiellońskiej”, 18, 1966, z. 2, s. 59-66

Kozłowska-Budkowa Z., Odnowienie jagiellońskie Uniwersytetu Krakowskiego (1390-1414), w: Dzieje Uniwersytetu Jagiellońskiego w latach 1364-1764, t. 1, red. K. Lepszy, Kraków 1964, s. 37-89

Krzyżaniakowa J., Eruditio et scientia w Dlugoszowych wizerunkach władców i biskupów, w: Mente et litteris. O kulturze i społeczeństwie wieków średnich, red. H. Chłopocka i in., Poznań 1984, s. 271-279

Krzyżaniakowa J., Otoczenie intelektualne Jana Długosza, w: Jan Długosz w pięćsetna rocznicę śmierci. Materiały z sesji (Sandomierz 24-25 maja 1980 r.), red. F. Kiryk, Olsztyn 1983, s. 31-43

Morawski K., Historia Uniwersytetu Jagiellońskiego. Średnie wieki i odrodzenie, t. 1-2, Kraków 1900

Ożóg K., Mistrza Mikołaja z Kozłowa pogląy na władzę i państwo, w: Ecclesia, cultura, potestas. Studia z dziejów kultury i społeczeństwa. Księga ofiarowana siostrze profesor Urszuli Borkowskiej, red. P. Kras i in., Kraków 2006, s. 419-429

Ożóg K., 'Ne contrarii haberemur doctrinae et scripturis nostris'. Droga Uniwersytetu Krakowskiego do złożenia obediencji papieżowi Mikołajowi V, w: Narodziny Rzeczypospolitej. Studia z dziejów średniowiecza i czasów wczesnonowożytnych, t. 2, red. W. Bukowski, T. Jurek, Kraków 2012, s. 1185-1204

Ożóg K., Zakres i metody nauczania ,septem artes” na Wydziale Sztuk Uniwersytetu Krakowskiego w XV wieku, w: Septem artes $w$ ksztaltowaniu kultury umystowej w Polsce średniowiecznej (wybrane zagadnienia), red. T. Michałowska, Wrocław 2007, s. 105-124

Ożóg K., Fokt K., Mikuła M., Zdanek M., Wójcik-Zega D., Kuras K., Profesorowie Wydziału Prawa Uniwersytetu Jagiellońskiego, t. 1: 1364-1780, red. W. Uruszczak, Kraków 2015

Perzanowska A., Wiadomości źródłowe o życiu i działalności Jana Długosza, w: Dlugossiana. Studia historyczne w pięćsetlecie śmierci Jana Dlugosza, red. S. Gawęda, Kraków 1980, s. 293-365

Pieradzka K., Jan Dlugosz a Uniwersytet Jagielloński, „Małopolskie Studia Historyczne”, 6, 1964, z. 3-4, s. 43-57

Pieradzka K., Związki Dtugosza z Krakowem, Kraków 1975

Pietrzyk Z., Poczet rektorów Uniwersytetu Jagiellońskiego 1400-2000, Kraków 2000

Polak W., Aprobata i spór. Zakon krzyżacki jako instytucja kościelna w dziełach Jana Długosza, Lublin 1999

Przybyszewski B., Kapituła krakowska za kanonikatu Jana Dtugosza (1436-1480), w: Dlugossiana. Studia historyczne w pięćsetlecie śmierci Jana Dtugosza, red. S. Gawęda, Kraków 1980, s. 25-82

Rabiej P., Uczeni uniwersyteccy w stużbie i otoczeniu Zbigniewa Oleśnickiego, biskupa krakowskiego, w: Polska i jej sąsiedzi w późnym średniowieczu, red. K. Ożóg, S. Szczur, Kraków 2000, s. 199-231

Stopka K., Na wieczysta pamiątke i symbol. Banderia Prutenorum: dzieło, autorzy, losy, w: J. Długosz, Banderia Prutenorum, red. Z. Pietrzyk, Kraków-Proszówki 2009, s. 13-46

Węcowski P., Mazowsze w Koronie. Propaganda i legitymizacja władzy Kazimierza Jagiellończyka na Mazowszu, Kraków 2004

Wiesiołowski J., Kolekcje historyczne w Polsce średniowiecznej XIV-XV wieku, Wrocław 1967

Wiesiołowski J., Sędziwój z Czechła (1410-1476). Studium z dziejów kultury umysłowej Wielkopolski, St. Źródł, 9, 1964, s. 75-104

Włodarek A., Architektura średniowiecznych kolegiów i burs Uniwersytetu Krakowskiego, Kraków 2000

Zarębski I., Humanistyczna lektura Dtugosza: Antonio Panormita Beccadelli, „Biuletyn Biblioteki Jagiellońskiej”, 17, 1965, z. 1, s. 5-21

Zathey J., Biblioteka Jagiellońska w latach 1364-1492, w: Historia Biblioteki Jagiellońskiej, t. 1, cz. 1, red. I. Zarębski, Kraków 1966, s. 3-130

Zwiercan M., Historia badań nad Jana Dąbrówki Komentarzem do „Kroniki polskiej” mistrza Wincentego zwanego Kadłubkiem, w: Komentarz Jana z Dąbrówki do Kroniki biskupa Wincentego, red. A. Dąbrówka, M. Olszewski, Studia Staropolskie, Series Nova, t. 42(98), Warszawa 2015, s. 15-27

Zwiercan M., Komentarz Jana z Dąbrówki do Kroniki mistrza Wincentego zwanego Kadłubkiem, Wrocław 1969

Zwiercan M., Rękopis Biblioteki Kapitulnej we Wrocławiu 5 n. Opis katalogowy, „Biuletyn Biblioteki Jagiellońskiej”, 17, 1965, z. 1, s. 23-28

Zwiercan M., Zainteresowania historyczne społeczności Uniwersytetu Krakowskiego w XV wieku, w: Literatura i kultura późnego średniowiecza w Polsce, red. T. Michałowska, Warszawa 1993, s. 41-56 